\title{
The Effectiveness of Concept Teaching Using Concept Maps on Academic Achievement and Elimination of Misconceptions: Protein Synthesis Case
}

\author{
Tuba Demirci ${ }^{1 *}$, Münir Oktay² \\ ${ }^{1}$ Department of Science Education, Faculty of Education, Alanya Alaaddin Keykubat University, Alanya, Turkey, ${ }^{2}$ Department of Primary School \\ Education, Faculty of Education, Karamanoğlu Mehmetbey University, Karaman, Turkey
}

*Corresponding Author: tuba.demirci@alanya.edu.tr

\section{ABSTRACT}

This study aimed to analyze the effectiveness of concept maps on the academic achievements of Biology teacher candidates and the elimination of misconceptions comparing the method with the traditional rote learning method. The quasi-experimental design, specifically, the pre- and post-test control group type was used in this research to address the research questions. The research was carried out with 60 Biology teacher candidates. Achievement test and diagnostic test were used as data collection tools throughout the research. SPSS version 20 software was used to analyze the obtained quantitative data. Independent samples t-test was used to determine, whether there was a significant difference between the control and experimental group students' level of prior knowledge regarding the subject of protein synthesis. The findings revealed no statistically significant difference between the groups in pre-test $(\rho>0.05)$. However, the findings revealed a statistically significant difference between the groups, in the post-test, in favor of the concept map method used for the experiment group $(\rho<0.05)$. The increase in the post-test scores of the experiment group students indicated that the teaching method based on concept maps positively affected the students' academic achievement and elimination of misconceptions. Research indicated that students could not establish a correct relationship between the concepts of DNA, RNA, mRNA, tRNA, rRNA, nucleus, chromosome, gene, genetic code, codon, anticodon, translation, transcription, ribosome, protein, and amino acid terms taught in protein synthesis subject. It was concluded that the areas of use for concept maps should not be limited as a teaching tool, but should be further extended to for determining misconceptions, eliminating misconceptions, and evaluating the instruction.

KEY WORDS: Concept map; concept teaching; misconception; protein synthesis

\section{INTRODUCTION}

D iscovering the structure and properties of DNA was one of the significant developments in the science of genetics (Watson and Crick, 1953). Following this discovery, concepts such as protein synthesis, DNA, RNA, and genes have begun to take place in teaching curricula (Yıldırım, 2008). Concept teaching is the task of ensuring that the concept to be taught is constructed in the mind of the child (Çayc1, 2006). The method to be chosen and used in concept teaching is important (Köksal, 2006). Providing the meanings of the concepts directly while teaching the concepts is not an effective method of conceptual teaching. In traditional conceptual teaching (rote learning) method, concepts are presented to students by introducing the concept, defining the concept, providing the descriptive and distinctive features of the concept, giving examples that are included and not included in the concept respectively (Kaptan, 1999). With this method, the student learns the concepts to a certain level. In modern conceptual teaching, which is another method used to ensure the effectiveness of concept teaching, the teacher asks the student to examine the examples that are included in the concept and to determine the descriptive and distinctive features accordingly. Effective and permanent conceptual teaching can be achieved by ensuring that concepts are learned together with their meanings, rather than encouraging students to memorize.

According to Ausubel (1968), meaningful learning takes place when former knowledge and new information are associated with each other and integrated in a cognitive structure. In meaningful learning, new concepts can be learned by bringing more detailed concepts together. More detailed concepts are referred to as advance organizers. Advance organizers may be an audio material, a picture, or a graphic. In any case, advance organizers should be designed to build a repertoire in the student's mind to learn new knowledge. According to Ausubel, learning takes place in three phases. These are Presentation of Advance Organizer, Presentation of the learning Task or Material, and Strengthening Cognitive organization. Ausubel's phases of learning are presented in Table 1.

Student-centered concept teaching methods help to improve the process of acquiring concepts correctly (Köksal, 2006). One of these methods is concept maps. Novak and Gowin (1984) suggested the term of utilizing concept maps in their work on "learning to learn." Concept maps, related to 


\begin{tabular}{lll}
\hline Table 1: Phases of meaningful learning (Ausubel, 1968) \\
\hline Phase one & Advance organizer & $\begin{array}{l}\text { Explicitly clarify aims of the lesson } \\
\text { Presentation of the advance } \\
\text { organizer } \\
\text { Relate the organizer to students } \\
\text { prior knowledge }\end{array}$ \\
Phase two & $\begin{array}{l}\text { Presentation of the } \\
\text { learning task or } \\
\text { material }\end{array}$ & $\begin{array}{l}\text { Clearly specifying the organization } \\
\text { of the new material } \\
\text { Logically sequencing the learning } \\
\text { material }\end{array}$ \\
& & $\begin{array}{l}\text { Engaging the students in } \\
\text { meaningful learning activities } \\
\text { Relate new information to advance } \\
\text { organizer } \\
\text { Phase three }\end{array}$ \\
& $\begin{array}{l}\text { Strengthening } \\
\text { cognitive organization active reception learning }\end{array}$ \\
\hline
\end{tabular}

meaningful learning, emerged as a result of the studies carried out by Joseph Novak and his students in the 1970s within the scope of a research project examining the issue of facilitating concept teaching in science education (Novak and Gowin, 1984). Concept maps are a method of establishing meaningful relationships between concepts and propositions. Novak suggests concept maps to be presented in a hierarchical order. New knowledge is learned based on the cognitive order and hierarchy of the concept maps. Cognitive order in concept maps has two significant contributions. The first is that knowledge is organized in line with a discipline and methodology. Ranking down in order of importance presents us the differences and relationships between successive concepts. Secondly, the visuality of the concept maps enables the students to perceive the connections more comfortably and thus facilitates the concept learning.

At the beginning of science courses, students are usually equipped with a number of concepts that are meaningful according to their own thinking structures but that conflict with scientific knowledge (Driver, 1991; Osborne and Wittrock, 1983; Treagust, 1988). Studies on explaining students' understanding of scientific concepts and the nature of science in a different way than those revealed by scientists are presented under different headings in the literature (Andersson, 1986; Griffiths and Preston, 1992). Students' acquisition of concept structures that conflict with the facts revealed by the scientific community are defined as misconception, preconception, alternative structures (Doran, 1972; Driver, 1981; Driver and Easley, 1978; Gabel and Bunce, 1994; Mike and Treagust, 1998; Nakhleh, 1994), children's science (Gunstone, 1990; Osborne and Freyberg, 1996; Treagust, 1988), and spontaneous knowledge (Champagne et al., 1983). As students learn new information, they combine it with the knowledge they have already acquired. The knowledge that students have previously acquired sometimes results in learning new concepts incorrectly. According to Piaget, misconceptions are such as a structure and continue by adding one on another. To eliminate misconceptions, incorrect information that students have acquired should be determined and replaced with the correct information to comply with the correct information to be further taught. The process of acquiring correct information, based on the constructivist learning theory, begins with determining the knowledge that students have acquired and teaching activities are prepared accordingly in line with this information (Stofflett, 1994). The process followed on this path, addressing correct information is referred to as the conceptual change (Smith and Blakeslee, 1993). The conceptual change approach developed by Posner and Gertzog (1982) based on the work of Piaget and Zeitgeist, emerges as a strategy based on Piaget's assimilation, accommodation, and equilibration principles (Chambers and Andre, 1997; Wang and Andre, 1991) and is an alternative approach that enables students to switch from non-scientific knowledge to scientifically revealed knowledge. During the assimilation phase students incorporate their existing knowledge and understanding in acquiring new concepts. Accommodation, on the other hand, is referred to as the step where the student reviews, modifies, organizes, and restructures their prior knowledge to be able to structure new concepts in their customized understanding (Canpolat and Pınarbaşı, 2002).

Studies examining misconceptions in the field of science education focus on determining misconceptions. However, trying to eliminate misconceptions is as important as detecting them. Elimination of misconceptions ensures that new information is not structured on the wrong ones; instead, it becomes important to teach the concept to be learned by associating it with other related concepts. Literature revealed that protein synthesis is a subject that students have had difficulty in learning (Lazarowitz and Penso, 1992; Marbach-Ad and Stavy, 2000; Membiela and Latorre, 1993; Pittman, 1999). It was further determined that students have had misconceptions about concepts such as DNA, RNA, transcription, translation, and gene taught under protein synthesis (Fisher, 1985; Kargbo et al., 1980; Saka et al., 2006). Diagnostic test is a method that is frequently used in the literature to determine misconceptions (Ayas, 2001). Diagnostic tests can be performed in the form of open-end tests or multiple-choice tests. While preparing the diagnostic test used in the research, the misconceptions found in the literature regarding the concepts taught on 'protein synthesis' subject were used (Demir, 2008; Fisher, 1985; Kargbo et al., 1980; Şahin \& Hacıoğlu, 2010; Saka and Akdeniz, 2004).

Although there are studies aiming to determine the misconceptions about protein synthesis subject in the literature, there are limited number of studies aimed at eliminating associated misconceptions. In addition, the number of studies in the literature examining eliminating misconceptions using concept maps is limited. Thus, it is important to find out the effects of conceptual teaching using concept maps to facilitate learning of protein synthesis concepts, which learners often have difficulty. This study aimed to analyze the effectiveness of concept maps on the academic achievements of Biology teacher candidates and elimination of misconceptions comparing the method with the traditional rote learning method. 


\section{METHOD}

This research was conducted using an experimental design with pre- and post-test control groups, also referred to as "quasiexperimental design" (McMillan and Schumacher, 2006). In quasi-experimental designs, a pre- and post-test are applied to the research groups. The data obtained as a result of the pre-test give us clues about whether the experiment and control groups were equal before the main experiment and allow us to interpret post-test results in the light of these findings. The experimental design used in the research is displayed in Table 2.

\section{Data Collection}

The research was carried out on 60 students from two different classes studying Biology Education at Atatürk University's Kazım Karabekir Faculty of Education in the spring semester of 2014-2015. All participants were volunteers and provided informed consent as part of the first authors $\mathrm{PhD}$ study. The participants of the experiment and control groups from within the classes selected with the convenience sampling. Analytic phase of the study lasted for a total of 6 weeks; 1-week pretest, 4-weeks trial, 1-week post-test. Teaching practices for the experiment and control groups were performed by the researcher in the classrooms of the faculty during Biology class hours. Teaching with the traditional method (rote learning) in the control group and the concept maps were prepared by the researcher on protein synthesis in the experiment group. At the end of the trials, academic achievement test and diagnostic test were re-applied to the experiment and control group students as a post-test to determine the extent to which the concept maps method has been beneficial for students. Some examples of concept maps (A, B, and C) prepared by the researcher on protein synthesis and used while lecturing are presented in Figures 1-3.

\section{Data Collection Tools}

"Academic Achievement Test" and "Diagnostic Test" were used as data collection tools throughout the research.

\section{Academic achievement test}

The academic achievement test addressed measuring the success level of Biology teacher candidates on the subject of "protein synthesis." This academic achievement test was developed as part of the first author's PhD study. The academic achievement test consists of 20 multiple-choice questions aimed at measuring the overall comprehension of bachelor's degree students about the "protein synthesis" unit. Validity of the questions in the test was checked by expert faculty members. Item analysis was performed for a total of 20 multiple-choice items in the test. For item analysis, firstly, the test scores of the students were calculated. While calculating, "1" point was given for each correct answer given in the test and " 0 " for each wrong answer. Then, scores of the students were ranked from the highest to the lowest. According to the results of this ranking, $8(30 * 27 / 100)$ students were determined from within each of the highest and lowest score groups. Then, item difficulty was calculated using the formula $\mathrm{p}=(\mathrm{UC}+$
LC) $/ 2 \mathrm{~N}$, and item discrimination was calculated using the formula $\mathrm{d}=(\mathrm{UC}-\mathrm{LC}) / \mathrm{N}(\mathrm{N}: 27 \%$ of the whole group, UC: The upper group of those giving correct answers, LC: The lower group of those giving correct answers). Discrimination criterion, at the end of item analysis, was evaluated taking into account the criteria specified in the study conducted by Çalık and Ayas (2003). Item difficulty and item discrimination values of each test item, derived at the end of item analysis, are displayed in Table 3.

Average item difficulty of 0.60 in the achievement test applied to the experiment group as per Table 3 indicates that the test is a medium difficulty test. In addition, an item discrimination score of 0.51 indicates that item discrimination of the test is "good." All these scores indicate that the item discriminations of the test are rather good and the items can be used without modification. Following the item analysis, reliability was checked. Kuder-Richardson Formula 20 (KR-20) reliability coefficient was calculated as 0.78 .

\section{Diagnostic test}

A20-question multiple-choice diagnostic test was also prepared by the first author as part of her PhD. This diagnostic test was prepared by making use of the misconceptions identified in the literature on this subject. Each question in the diagnostic test has five optional answers; each question has four distracter options and one correct answer. Available options include

\begin{tabular}{|c|c|c|c|c|}
\hline Major & Group & Pre-test & Application & Post-test \\
\hline \multirow[t]{2}{*}{$\begin{array}{l}\text { Biology } \\
\text { education }\end{array}$} & $\begin{array}{l}\text { Control } \\
\text { group }\end{array}$ & $\begin{array}{l}\text { Achievement } \\
\text { test }\end{array}$ & $\begin{array}{l}\text { Traditional } \\
\text { rote learning }\end{array}$ & $\begin{array}{l}\text { Achievement } \\
\text { test }\end{array}$ \\
\hline & & Diagnostic test & & $\begin{array}{l}\text { Diagnostic } \\
\text { test }\end{array}$ \\
\hline \multirow[t]{2}{*}{$\begin{array}{l}\text { Biology } \\
\text { education }\end{array}$} & $\begin{array}{l}\text { Experiment } \\
\text { group }\end{array}$ & $\begin{array}{l}\text { Achievement } \\
\text { test }\end{array}$ & Concept maps & $\begin{array}{l}\text { Achievement } \\
\text { test }\end{array}$ \\
\hline & & Diagnostic test & & $\begin{array}{l}\text { Diagnostic } \\
\text { test }\end{array}$ \\
\hline
\end{tabular}

Table 3: Item analysis according to the number of correct answers given by the students in the lower and upper groups

\begin{tabular}{lccccccccc}
\hline Question & UC & LC & $\mathbf{p}$ & $\mathbf{d}$ & Question & UC & LC & $\mathbf{p}$ & $\mathbf{d}$ \\
\hline 1 & 7 & 4 & 0.69 & 0.38 & 11 & 8 & 2 & 0.63 & 0.75 \\
2 & 8 & 6 & 0.88 & 0.25 & 12 & 8 & 0 & 0.50 & 1.00 \\
3 & 8 & 3 & 0.69 & 0.63 & 13 & 8 & 1 & 0.56 & 0.88 \\
4 & 7 & 3 & 0.63 & 0.50 & 14 & 8 & 3 & 0.69 & 0.63 \\
5 & 2 & 0 & 0.13 & 0.25 & 15 & 8 & 4 & 0.75 & 0.50 \\
6 & 8 & 3 & 0.69 & 0.63 & 16 & 7 & 1 & 0.50 & 0.75 \\
7 & 6 & 2 & 0.50 & 0.50 & 17 & 7 & 4 & 0.69 & 0.38 \\
8 & 5 & 0 & 0.31 & 0.63 & 18 & 7 & 4 & 0.69 & 0.38 \\
9 & 8 & 3 & 0.69 & 0.63 & 19 & 8 & 6 & 0.88 & 0.25 \\
10 & 6 & 1 & 0.44 & 0.63 & 20 & 5 & 3 & 0.50 & 0.25 \\
\hline
\end{tabular}

UC: The upper group of those giving correct answers $(27 \%=8$ students); LC: The lower group of those giving correct answers $(27 \%=8$ students); $\mathrm{p}$ : item difficulty; d: item discrimination 


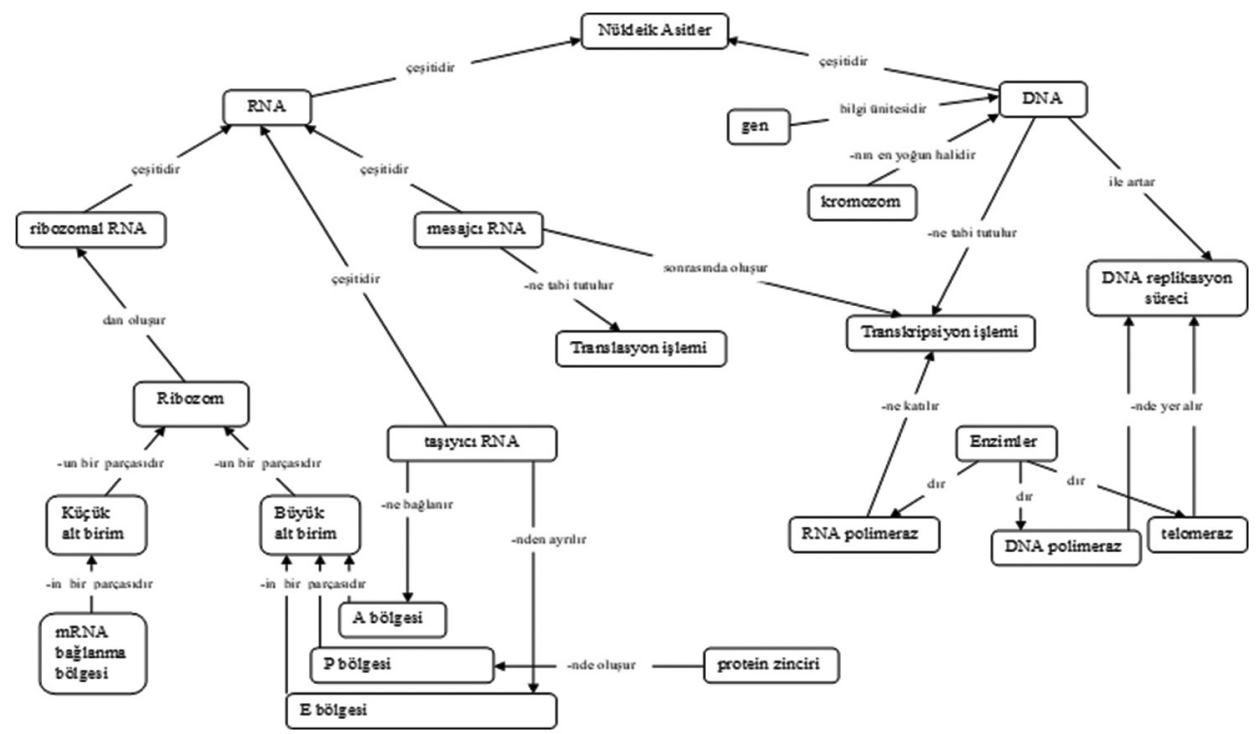

Figure 1: Protein synthesis concept map A

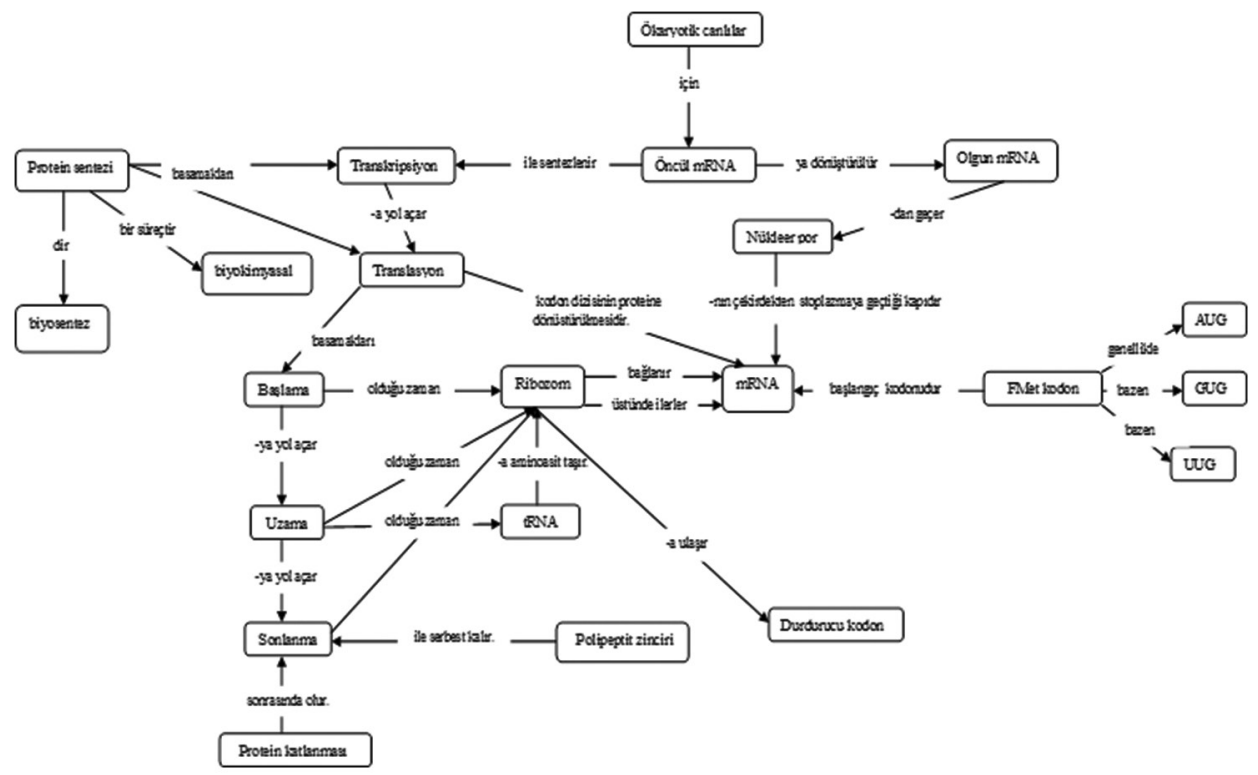

Figure 2: Protein synthesis concept map B

distracters that contain misconceptions. The relationships between concepts such as nucleus, DNA, gene, genetic code, chromosome, RNA, rRNA, mRNA, tRNA, codon, anti-codon, amino acid, protein, ribosome, transcription, translation, and protein synthesis were questioned in the diagnostic test.

Validity of the questions in the test was checked by expert faculty members. Item analysis was performed for the test prepared after taking the expert opinion. Item difficulty and item discrimination values of each test item are displayed in Table 4.

Average item difficulty of 0.43 in the diagnostic test applied to the experiment group as per Table 4 indicates that the test is a medium difficulty test. In addition, an item discrimination score of 0.55 indicates that item discrimination of the test is 'good'. These scores indicate that item discrimination of the test is quite good in accordance with the criteria stipulated in the study by Çalık and Ayas (2003), and the items can be used without any modification. Following the item analysis, reliability of the test was checked. Kuder-Richardson Formula 20 (KR-20) reliability coefficient was calculated as 0.93 .

\section{Data Analysis}

T-test for independent groups was used in analyzing the quantitative data obtained in the experimental study.

\section{FINDINGS AND COMMENTS}

This section covers the findings and comments about the scores in academic achievement test and diagnostic test. 


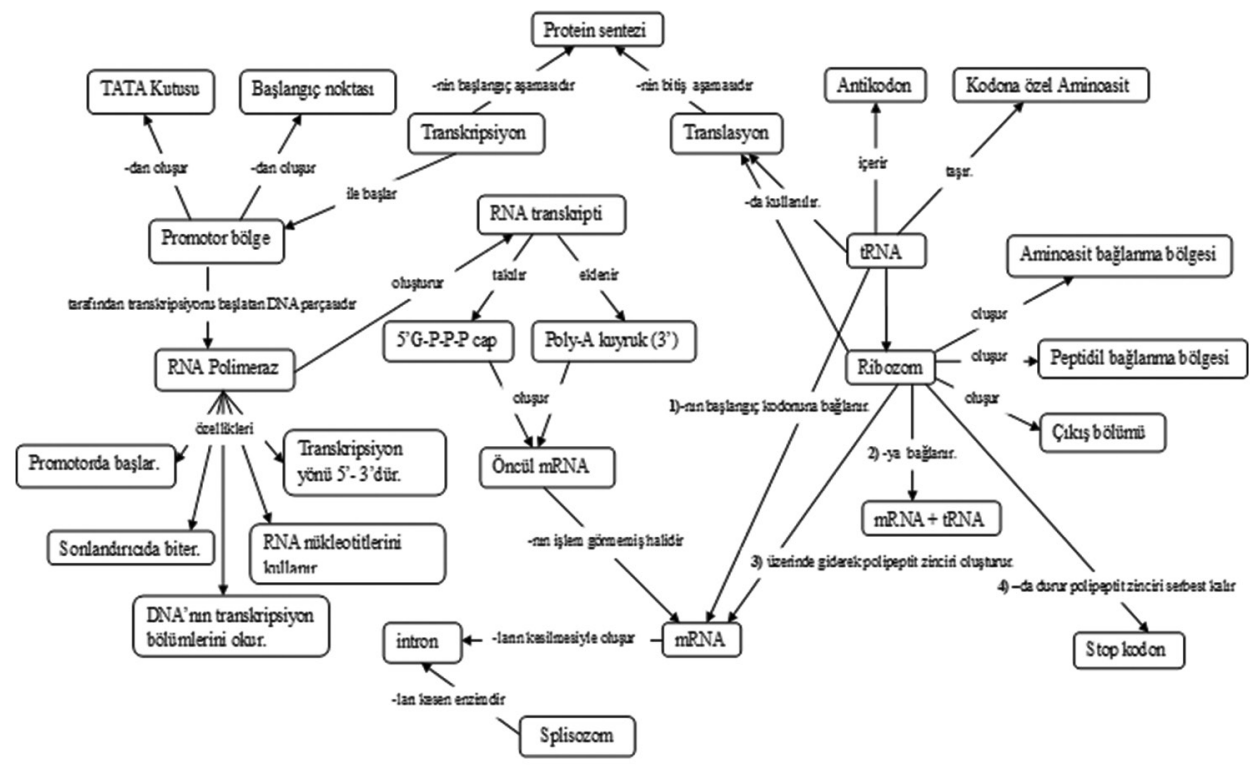

Figure 3: Protein synthesis concept map C

\begin{tabular}{|c|c|c|c|c|c|c|c|c|c|}
\hline Question & UC & LC & $p$ & d & Question & UC & LC & $p$ & d \\
\hline 1 & 8 & 6 & 0.88 & 0.25 & 11 & 7 & 0 & 0.44 & 0.88 \\
\hline 2 & 8 & 2 & 0.63 & 0.75 & 12 & 8 & 0 & 0.50 & 1.00 \\
\hline 3 & 7 & 3 & 0.63 & 0.50 & 13 & 8 & 1 & 0.56 & 0.88 \\
\hline 4 & 7 & 3 & 0.63 & 0.50 & 14 & 8 & 1 & 0.56 & 0.88 \\
\hline 5 & 4 & 1 & 0.31 & 0.38 & 15 & 8 & 1 & 0.56 & 0.88 \\
\hline 6 & 8 & 1 & 0.56 & 0.88 & 16 & 4 & 0 & 0.25 & 0.50 \\
\hline 7 & 8 & 0 & 0.50 & 1.00 & 17 & 3 & 0 & 0.19 & 0.38 \\
\hline 8 & 8 & 1 & 0.56 & 0.88 & 18 & 4 & 1 & 0.31 & 0.38 \\
\hline 9 & 6 & 2 & 0.50 & 0.50 & 19 & 8 & 2 & 0.63 & 0.75 \\
\hline 10 & 4 & 1 & 0.31 & 0.38 & 20 & 4 & 0 & 0.25 & 0.50 \\
\hline
\end{tabular}

UC: The upper group of those giving correct answers $(27 \%=8$ students); LC: The lower group of those giving correct answers ( $27 \%=8$ students); $\mathrm{p}$ : item difficulty; $\mathrm{d}$ : item discrimination

\section{Evaluation of the Academic Achievement Pre-test Findings of the Experiment and Control Groups}

Independent samples t-test was applied to determine whether there was a significant difference between the experiment and control groups in terms of academic achievement test scores before the instruction (lecture). The findings obtained are presented in Table 5.

The results of the independent samples t-test performed to determine whether the difference between the arithmetic mean of pre-instruction academic achievement pre-test scores of experiment and control groups, which were 7.23 and 7.68, respectively, was significant or not is presented in Table 5 which reveals that the difference was found to be insignificant, $\mathrm{t}(53)=-0.875, \rho>0.01$.

$\begin{aligned} & \text { Table 5: Academic achievement pre-test results of } \\
& \text { experiment and control groups }\end{aligned}$
\begin{tabular}{lccccc}
\hline Groups & $\mathbf{n}$ & $\mathbf{X}$ & Ss & $\mathbf{t}$ & $\mathbf{\rho}$ \\
\hline Academic achievement test & & & & & \\
$\quad$ Experiment group & 30 & 7.23 & 2.02 & -0.875 & 0.386 \\
$\quad$ Control group & 30 & 7.68 & 2.77 & & \\
\hline
\end{tabular}

Table 6: Academic achievement post-test results of experiment and control groups

\begin{tabular}{lccccc}
\hline Groups & $\mathbf{n}$ & $\mathbf{X}$ & Ss & $\mathbf{t}$ & $\mathbf{\rho}$ \\
\hline Academic achievement test & & & & & \\
$\quad$ Experiment group & 30 & 11.66 & 4.42 & 3.742 & 0.000 \\
Control group & 30 & 7.80 & 3.17 & & \\
\hline
\end{tabular}

Table 7: Diagnostic pre-test results of experiment and control groups

\begin{tabular}{lccccc}
\hline Groups & $\mathbf{n}$ & $\mathbf{X}$ & Ss & $\mathbf{t}$ & $\boldsymbol{\rho}$ \\
\hline $\begin{array}{l}\text { Diagnostic test } \\
\begin{array}{l}\text { Experiment } \\
\text { group }\end{array}\end{array}$ & 30 & 6.40 & 2.42 & 0.445 & 0.658 \\
$\quad$ Control group & 30 & 5.20 & 2.21 & & \\
\hline
\end{tabular}

Evaluation of the Academic Achievement Post-test Findings of the Experiment and Control Groups

Independent samples t-test was applied to determine whether there was a significant difference between the experiment and control groups in terms of academic achievement test scores after the instruction (lecture). The findings obtained are presented in Table 6 . 
Table 8: Diagnostic post-test results of experiment and control groups

\begin{tabular}{lccccc}
\hline Groups & $\mathbf{n}$ & $\mathbf{X}$ & Ss & $\mathbf{t}$ & $\boldsymbol{\rho}$ \\
\hline Diagnostic test & & & & & \\
Experiment group & 30 & 9.67 & 5.53 & 3.996 & 0.000 \\
Control group & 30 & 6.12 & 2.40 & & \\
\hline
\end{tabular}

The results of the independent samples t-test performed to determine whether the difference between the arithmetic mean of post-instruction academic achievement post-test scores of experiment and control groups, which were 11.66 and 7.80, respectively, was significant or not is presented in Table 6 which reveals that the difference was found to be significant, $\mathrm{t}(54)=3.742, \rho<0.01$. All these findings indicate that there

Table 9: Misconceptions and their numbers observed in the experiment and control groups

\begin{tabular}{|c|c|c|c|c|}
\hline Misconceptions & CG pre test \% & CG post test \% & EG pre test \% & EG post test \% \\
\hline Genes are bigger than DNA & 16 & 10 & 12 & 4 \\
\hline Gene and DNA are the same concepts & 10 & 8 & 10 & 5 \\
\hline Genes rule the DNA & 12 & 8 & 8 & 4 \\
\hline Gene and DNA are separate components & 18 & 12 & 8 & 4 \\
\hline DNA should be paired first to synthesize mRNA from genes & 34 & 32 & 33 & 7 \\
\hline mRNA transfers the code it receives from genes to tRNA & 10 & 8 & 6 & 2 \\
\hline Only mRNA is synthesized by gene transcription & 42 & 40 & 37 & 8 \\
\hline Chromosomes make up DNA & 20 & 26 & 25 & 12 \\
\hline Chromosomes and DNA are the same concepts & 12 & 10 & 9 & 8 \\
\hline Chromosomes and DNA are separate components & 10 & 12 & 11 & 6 \\
\hline DNA structure consists of chromosomes & 22 & 24 & 23 & 14 \\
\hline Chromosomes are carried over genes & 13 & 12 & 13 & 10 \\
\hline Genes are made up of chromosomes that come together & 12 & 8 & 9 & 8 \\
\hline Chromosomes and genes are separate components & 15 & 14 & 12 & 7 \\
\hline Chromosomes are made up of genes only & 13 & 12 & 10 & 9 \\
\hline $\begin{array}{l}\text { The structure of the gene consists of DNA, and the structure of } \\
\text { DNA consists of chromosomes }\end{array}$ & 22 & 20 & 24 & 10 \\
\hline $\begin{array}{l}\text { There is DNA on the chromosome, DNAs are components of } \\
\text { genes }\end{array}$ & 25 & 24 & 23 & 8 \\
\hline Chromosomes make up DNAs, genes make up chromosomes & 22 & 18 & 26 & 11 \\
\hline In prokaryotic organisms, DNA is found in the nucleus & 19 & 17 & 15 & 12 \\
\hline In eukaryotic organisms, DNA is not found in the nucleus & 17 & 16 & 13 & 12 \\
\hline $\begin{array}{l}\text { Since prokaryotic organisms do not have a nucleus, they do not } \\
\text { have DNA either }\end{array}$ & 21 & 20 & 21 & 12 \\
\hline There is protein in the structure of DNA & 35 & 31 & 28 & 12 \\
\hline $\begin{array}{l}\text { The total number of nucleotides and the total number of sugars } \\
\text { in a DNA molecule may be different }\end{array}$ & 25 & 24 & 17 & 12 \\
\hline DNA is not involved in protein synthesis & 18 & 11 & 12 & 10 \\
\hline $\begin{array}{l}\text { mRNA is synthesized after the subcomponents of the ribosome } \\
\text { are joined }\end{array}$ & 16 & 14 & 11 & 8 \\
\hline tRNA is read in the ribosome, not the mRNA & 24 & 20 & 13 & 10 \\
\hline The mRNA should be recognized to be read in the ribosome & 18 & 12 & 10 & 9 \\
\hline Amino acid is synthesized after reading the mRNA & 20 & 18 & 12 & 10 \\
\hline $\begin{array}{l}\text { The codon available in the DNA structure corresponds to } \\
\text { anti-codon }\end{array}$ & 42 & 40 & 38 & 25 \\
\hline $\begin{array}{l}\text { The codon available on the tRNA pairs with the anti-codon } \\
\text { available on the mRNA }\end{array}$ & 12 & 15 & 18 & 16 \\
\hline $\begin{array}{l}\text { Anticodon is located opposite the codon during the pairing of } \\
\text { the DNA }\end{array}$ & 22 & 20 & 19 & 16 \\
\hline $\begin{array}{l}\text { Protein, amino acid and tRNA are synthesized according to the } \\
\text { genetic code }\end{array}$ & 20 & 18 & 19 & 17 \\
\hline $\begin{array}{l}\text { The building blocks of protein, amino acids, and tRNA are the } \\
\text { same }\end{array}$ & 22 & 21 & 23 & 20 \\
\hline $\begin{array}{l}\text { The tRNA transmits code to the ribosome, subunits are formed, } \\
\text { and protein is synthesized }\end{array}$ & 27 & 25 & 20 & 18 \\
\hline tRNA forms amino acids together with the ribosome & 23 & 20 & 21 & 20 \\
\hline
\end{tabular}

CG: Control group, EG: Experiment group 
was a significant difference between the experiment and control groups in terms of post-instruction academic achievement test.

\section{Evaluation of the Diagnostic Pre-test Findings of the Experiment and Control Groups}

The mean and standard deviations of pre-test scores obtained from the diagnostic test of the experiment and control groups were calculated. Independent samples t-test was applied to determine whether there was a significant difference between the experiment and control groups in terms of diagnostic test scores before the instruction (lecture). The findings obtained are presented in Table 7.

The results of the independent samples t-test performed to determine whether the difference between the arithmetic mean of pre-instruction diagnostic pre-test scores regarding the misconception of experiment and control groups, which were 6.40 and 5.20, respectively, was significant or not is presented in Table 7 which reveals that the difference was found to be insignificant, $\mathrm{t}(55)=0.445, \rho>0.01$.

\section{Evaluation of the Diagnostic Post-test Findings of the Experiment and Control Groups}

The mean and standard deviations of post-test scores obtained from the diagnostic test of the experiment and control groups were calculated. Independent samples t-test was applied to determine whether there was a significant difference between the experiment and control groups in terms of post-instruction diagnostic test scores. The findings obtained are presented in Table 8 .

The results of the independent samples t-test performed to determine whether the difference between the arithmetic mean of post-instruction diagnostic post-test scores of experiment and control groups, which were 9.67 and 6.12 respectively, was significant or not is presented in Table 8 which reveals that the difference was found to be significant, $t(55)=3.996$, $\rho<0.01$. All these findings indicate that there was a significant difference between the experiment and control groups in terms of post-instruction diagnostic test.

Pre- and post-instruction misconceptions and their numbers observed in the experiment and control groups are descriptively presented in Table 9.

Table 9 reveals that the misconceptions most frequently encountered in the experiment and control groups were: "mRNA transfers the code it receives from genes to tRNA," "The codon available in the DNA structure corresponds to anti-codon," "There is protein in the structure of DNA," "DNA should be paired first to synthesize mRNA from genes," "There is DNA on the chromosome, DNAs are components of genes", "DNAs are also gene components" "tRNA is read in the ribosome, not the mRNA," and "DNA structure consists of chromosomes."

A descriptive analysis of Table 9 reveals that number of postinstruction misconceptions observed in both the experiment and control groups were reduced. However, the decrease in the number of misconceptions observed in the experimental group was greater.

\section{DISCUSSION AND CONCLUSION}

Pre-instruction academic achievement pre-test scores of both groups applied throughout the research have revealed no statistically significant difference between the groups $(\rho>0.05)$, and pre-test academic achievement test scores of both groups were relatively low. Equivalent success levels of both research groups are considered to be significant in terms of evaluating the objectivity of the research. However, the findings obtained from the post-test achievement tests applied following the instruction, revealed a statistically significant difference between the groups in favor of the experiment group $(\rho<0.05)$. This increase observed in the post-test scores of the experiment group students can be interpreted as an indicator revealing that the teaching method based on concept maps had a positive effect on these students' achievement.

This result seems to be supported by the studies available in the literature. A study conducted by Franklin (1991) to examine the effect of using concept maps on the scientific achievement of the $8^{\text {th }}$ grade students revealed that students who study science with concept maps were more successful than students who studied with the traditional method. A study conducted by Horton et al. (1993) aiming to examine experimental studies on concept maps revealed that the success rate was higher in classes where teaching was performed with concept maps. Another study conducted by Lord (1999) revealed that academic achievement of students who were taught with concept maps were higher. Öner and Arslan (2005), in their research findings, revealed that the learning and remembering levels of the experiment group who were taught the unit of "Electricity" with concept maps were higher compared to the control group who were taught using the traditional rote learning. The study conducted by Kasapoğlu (2011) revealed that teaching with concept maps had a positive effect on students' academic achievements and attitudes.

Kazanc1 et al. (2003), in their study, compared the role of concept maps with traditional teaching methods on students' learning the genetics. While traditional teaching methods (rote learning) was applied in the control group, concept maps were used in addition to traditional teaching method in the experiment group. The level of success of the students in two research groups was compared with the t-test, and it was concluded that the group that were taught with the help of concept maps was more successful compared to the group that was taught with the traditional teaching method. A study conducted by Çağlayan (2006) aiming to examine the effect of using concept maps while teaching the unit on genetics on students' academic achievements and the ability to gain concepts revealed that making use of concept maps while teaching the unit on genetics positively affects academic achievement. Güneş et al. (2006), with the aim to examine the effects of using concept maps on academic achievement, 
identified 8 biology units within the scope of Biology II course and then formed an experiment and a control group from within second grade students who were studying science teaching. The students in the control group were taught with the traditional teaching method, whereas the students in the experiment group were first taught with the traditional teaching method but further asked to prepare a concept map related to the subjects. The experiment group who were asked to prepare concept maps was found to be more successful compared to the control group who were lectured using the traditional teaching method.

A study conducted by Güçlüer (2006) aiming to examine the effect of cognitive support provided by using concept maps in primary school science education on academic achievement, ability to remember concepts and students' attitudes toward science course revealed that the teaching method, supported by concept maps, is more effective than the traditional teaching method. Şan (2008) examined the effect of teaching $10^{\text {th }}$ grade high school students the transport system in plants in the biology class using concept maps on students' academic success and revealed that the approach of using concept maps significantly improved academic achievement compared to traditional teaching. In a study conducted by Akay (2010), a 45-question biology achievement test was applied as a pretest to both the experiment group instructed using concept maps and the control group instructed with traditional rote learning, and it was concluded that there was no statistically significant difference between the groups in terms of academic achievement. Considering the post-test scores applied after the instruction, the experiment group instructed using concept maps had higher average score compared to that of the control group instructed with traditional rote learning and that the difference between the groups was statistically significant. A study conducted by Aksoy (2010) revealed that instructing the subject with concept maps in secondary school chemistry class is more effective in increasing scientific achievement and improving students' attitude to chemistry compared to teaching with the traditional method. The study conducted by Aktaş (2012) indicated significantly higher academic achievement post-test mean scores than their pre-test mean scores. This finding supported the inference in the experimental group that science and technology education supported by concept maps contributed positively to students' academic achievement.

The findings obtained from the diagnostic test applied to the experiment and control groups as a pre-test revealed no statistically significant difference between the groups $(\rho>0.05)$ and indicated that both groups were at the same level. However, the findings obtained from the post-test diagnostic tests applied following the instruction, revealed a statistically significant difference between the groups in favor of the experiment group $(\rho<0.05)$. This increase observed in the post-test scores of the experiment group students can be interpreted as an indicator revealing that the teaching method based on concept maps has a positive effect on students' academic achievement. Studies encountered in the literature review examining the role of concept maps on overcoming misconceptions are found out to be supporting the findings of this study (Aykanat et al., 2005; Çalık and Ayas, 2003; Gürlek, 2002; Kaptan, 1998; Markham and Mintzes, 1993).

The study conducted by Çardak (2002) defined the misconceptions that the students had about the unit on diversity and classification of living organisms and to eliminate the misconceptions on this subject determined that the conceptual change texts provided with concept maps have a positive effect on the elimination of misconceptions. Atasoy (2002), in the study on concept maps, stated that concept maps can be used to discuss the meanings of concepts with students, identify and resolve misunderstandings and alternative concepts.

Research indicated that students had wrong and incomplete information about and could not establish a correct relationship between the concepts of DNA, RNA, mRNA, tRNA, rRNA, nucleus, chromosome, gene, genetic code, codon, anti-codon, translation, transcription, ribosome, protein, and amino acid terms taught in protein synthesis subject. This result seems to be supported by the studies available in the literature. The study conducted by Kargbo et al. (1980) concluded that chromosome and gene relationship are difficult concepts to learn. The study conducted by Fisher (1985) stipulated that students did have misconceptions about the concepts of translation and amino acids in the translation phase of protein synthesis. Similarly, Banet and Ayuso (2000) revealed that students understand basic concepts such as gene and chromosome incorrectly or incompletely. In the study conducted by Lewis et al. (2000), $18 \%$ of the students who tried to explain the relationship between the concepts of gene, chromosome and nucleus stated that chromosomes are larger than the nucleus. The study conducted by Wood-Robinson et al. (2000) stated that students were frequently confused about the relationships between the concepts of gene, DNA and chromosomes. Saka and Akdeniz (2004), on the other hand, identified in their study that some pre-service science teachers had misconceptions about concepts like chromosome, gene, and DNA. Findings derived from the conceptual understanding test and interviews conducted with students included in the study by Bedir (2007) revealed that students establish wrong relationships between difficult to learn concepts such as gene, DNA and chromosomes and they have misconceptions about these concepts. Academic achievement tests were used in the study conducted by Demir (2008) with the aim to compare the changes between experiment and control group students in terms of their academic achievements. There was a significant decrease in terms of success regarding the experiment and control groups in terms of the answers given to the informative questions about protein synthesis. Majority of the questions where more than $50 \%$ of the students could not answer in both the control and experiment groups are reported to be related to DNA, RNA, protein synthesis and nucleotides. The study by Altınay (2009) revealed that students frequently had misconceptions about concepts like gene, DNA, and chromosomes. The most common misconceptions observed in students on this issue 
were found to be that DNA is a smaller structure than a gene and that chromosomes are carried over genes. Can and Vural (2011) identified in their study that some candidate science teachers had difficulty in associating the concepts of DNA, chromosome, and genes with each other.

Concept maps method can be used for students to make sense of micro-dimension concepts such as protein synthesis and to facilitate them to make connections between these concepts. As students are used to the traditional method of instruction (rote learning), they may feel unfamiliar with lectures instructed with concept maps. Therefore, the concept map approach should be explained to the students in detail before instructing with concept maps. Concept map is an alternative method in education. Therefore, the use of concept map with other methods may further reinforce learning.

\section{ACKNOWLEDGMENTS}

This article was produced from the doctoral dissertation of Tuba Demirci, conducted under the supervision of Münir Oktay.

\section{REFERENCES}

Akay, S. (2010). The Effect on the Academic Achievement and Attitudes of Students of Teaching Via Concept Maps the Subject of Excretory System Studies in the Course Biology of High School Grade. Konya: Unpublished Master's Thesis, Selçuk University, Institute of Educational Sciences.

Aksoy, M. (2010). The Effects to the Success and Behaviors of the Students to be taught by the Concept Map of Solubility Subject in the Chemistry Lessons at Secondary Education. Konya: Unpublished Master's Thesis, Selçuk University, Institute of Educational Sciences.

Aktaş, Ö. (2012). The Effects of Science and Technology Education Supported by Concept and Mind Mapping on Learning Products in Primary Education. İzmir: Unpublished Master's Thesis, Dokuz Eylül University, Institute of Educational Sciences.

Altınay, Ö. (2009). The Effects of the Teaching Method Based on the 5E Model on Eighth Grade Students Understanding of the Concepts of Related to Genetics, DNA, Gene, and Chromosome. Balıkesir: Unpublished Master's Thesis, Balıkesir University, Institute of Educational Sciences.

Andersson, B. (1986). Pupils' explanations of some aspects of chemical reactions. Science Education, 70(5), 549-563.

Atasoy, B. (2002). Science Education and Teaching. Gündüz Eğitim and Yayıncilik.

Ausubel, D.P. (1968). Educational Psychology: A Cognitive View. New York: Holt, Rinehart and Winston.

Ayas, A. (2001). Students level of understanding of five basic chemistry concepts. Boğaziçi University Journal of Education, 18, 19-33.

Aykanat, F., Doğru, M., \& Kalender, S. (2005). The effect of science instruction by the computer-based concept maps method on the students' achievement. Kastamonu University Journal of Education, $3(2), 391-400$

Banet, E., \& Ayuso, E. (2000). Teaching genetics at secondary school: A strategy for teaching about the location of inheritance information. Science Education, 84, 313-351.

Bedir, G. (2007). The Effect of New Primary Science and Technology Course Curriculum on Students' Conceptual Understanding: A Case Study on Cell Division and Inheritance Unit. Balıkesir: Unpublished Master's Thesis, Balıkesir University, Institute of Educational Sciences.

Çağlayan, Ç. (2006). The Effect of Using Concept Maps on Scholar Success of Student and Their Learning of New Concepts When Teaching Genetics Unit of Science on Eighth Grade. Adana: Unpublished Master's Thesis, Çukurova University, Institute of Educational Sciences.
Çalık, M., \& Ayas, A. (2003). Preparing and applying concept success test in solutions [Çözeltilerde kavram başarı testi hazırlama ve uygulama]. Pamukkale University Journal of Faculty of Education, 2(14), 1-17.

Can, H., \& Vural, R.A. (2011). Science teachers' knowledge level of the chromosome concept and opinions on teaching the concept. [Fen bilgisi öğretmen adaylarının kromozom kavramına ilişkin bilgi düzeyi ve kavramın öğretilmesine ilișkin görüşleri]. Hasan Ali Yücel Journal of Faculty of Education, 8(2), 1-21.

Canpolat, N., \& Pınarbaşı, T. (2002). Conceptual change approach in science education: Theoretical basis. G.Ü. Kastamonu University Journal of Education, 13(2), 391-400.

Çardak, O. (2002). The Identification of Misconceptions of High Frechmen on the Variety and Classification of Living Things and Correction of Them through Concepts Maps. Konya: Unpublished Doctoral Thesis, Selçuk University, Institute of Educational Sciences.

Çayc1, B. (2006). The effect of conceptual change texts on the concept learning. Gazi University Gazi Journal of Education, 27(1), 87-102.

Chambers, K.S., \& Andre, T. (1997). Gender, prior knowledge, interest and experience in electricity and conceptual change text manipulations in learning about direct current. Journal of Research in Science Teaching, $34,107-123$.

Champagne, A.D., Gunstone, R.F., \& Klopfer, L.E. (1983). Naive knowledge and science learning. Research in Science and Technology Education, $1(2), 173-183$

Demir, A. (2008). The Use of Graphic Materials for Determining and Overcoming Misconceptions on Genetic Chapter in Primary School Eight $\left(8^{\text {th }}\right)$ Grade Science Education (Science and Technology) Lesson. Erzurum: Unpublished Master's Thesis, Atatürk University, Institute of Educational Sciences.

Doran, R.L. (1972). Misconception of selected science concepts held by elementary school students. Journal of Research in Science Teaching, 9(2), 127-137.

Driver, R. (1981). Pupils alternative framework in science. European Journal of Science Education, 3, 91-101.

Driver, R. (1991). The Pupils as Scientist? Bristol, USA: Open University Press.

Driver, R., \& Easley, J. (1978). Pupils and paradigms: A review of literature related to concept development in adolescent science students. Studies in Science Education, 5, 61-84.

Fisher, K.M. (1985). A misconception in biology: Amino acids and translation. Journal of Research in Science Teaching, 22(1), 53-62.

Franklin, C.E. (1991). An experiment testing the effects of concept mapping on science anxiety and acquisition of scientific knowledge among eighth-grade students low in integrative complexity. Dissertation Abstracts International, 52, 1689A.

Gabel, D.L., \& Bunce, D.M. (1994). Research on Problem Solving: Chemistry. In: Gabel, D.L., (Ed.), Handbook of Research on Science Teaching and Learning. London, United Kingdom: Macmillan. pp. 301-326.

Griffiths, A.K. \& Preston, K.R. (1992). Grade-12 students' misconceptions relating to fundamental characteristics of atoms and molecules. Journal of Research in Science Teaching, 29(6), 611-628.

Güçlüer, E. (2006). The Effect of Cognitive Support Given by Concept Mapping on Achievement, Retention and Attitude in Primary Science Education. İzmir: Unpublished Master's Thesis, Dokuz Eylül University, Institute of Educational Sciences.

Güneş, M.H., Çelikler, D., \& Güneş, T. (2006). Using the concept map technique to better understand the nervous system. [Sinir sisteminin daha iyi anlaşılması için kavram haritası tekniğinin kullanılması]. Ondokuz Mayls University Journal of Education Faculty, 20, 70-76.

Gunstone, R.F. (1990). Children's science: A decade of developments in constructivist views of science teaching and learning. The Australian Science Teachers Journal, 36(4), 9-19.

Gürlek, M. (2002). The Practising of maps web conceptions and the tableaues of meaning solutions at secondary instruction teaching biology. Van: Unpublished Master's Thesis, Yüzüncü Y1l University, Institute of Educational Sciences.

Horton, P.B., Mc Conney, A.A., Gallo, M., Woods, A.L., Senn, G.J., \& Hamelin, D. (1993). An investigation of the effectiveness of concept mapping as an instructional tool. Science Education, 77(1), 95-111.

Kaptan, F. (1998). The use of concept map technique in science education. 
Hacettepe University Journal of Education, 14, 95-99.

Kaptan, F. (1999). Science Teaching [Fen Bilgisi Öğretimi]. India: Ministry of Education.

Kargbo, D.B., Hobbs, E.D., \& Erickson, G.L. (1980) Children's beliefs about inherited characteristics. Journal of Biological Education, 14, 137-146.

Kasapoğlu, E. (2011). The Effect of Teaching Protein Synthesis Using Concept Maps on the Academic Achievement and Attitudes of $12^{\text {th }}$ Grade High School Students. Konya: Unpublished Master's Thesis, Selçuk University, Institute of Educational Sciences.

Kazancı, M., Atılboz, N.G., Doğan, B.N., \& Altın, M. (2003). The effect of concept mapping on $11^{\text {th }}$ grade students' learning of genetics. Hacettepe University Journal of Education, 25, 135-141.

Köksal, M.S. (2006). Concept teaching and multiple intelligences theory. Kastamonu University Journal of Education, 14(2), 473-480.

Lazarowitz, R., \& Penso, S. (1992). High school student's difficulties in learning biology concepts. Journal of Biological Education, 26(3), 215-223.

Lewis, J., Leach, J., \& Wood-Robinson, C. (2000). All in the genes? Young people understanding of the nature of genes. Educational Research, 34(2), 74-79.

Lord, T. (1999). A comparison between traditional and constructivist teaching in environmental science. The Journal of Environmental Education, 30(3), 22-28.

Marbach-Ad, G., \& Stavy, R. (2000). Student's cellular and molecular explanation of genetic phenomena. Journal of Biological Education, 34(4), 200-205.

Markham, K.M., \& Mintzes, J.J. (1993). The concept map as a research and evaluation tool: Further evidence of validity. Journal of Research in Science Teaching, 31(1), 91-101.

McMillan, J.H., \& Schumacher, S. (2006). Research in Education: Evidencebased Inquiry. $6^{\text {th }}$ ed. Boston, MA: Allyn and Bacon.

Membiela, P., \& Latorre, P. (1993). A model for demonstrating protein synthesis. Journal of Biological Education, 27(2), 92-95.

Mike, M., \& Treagust, D.F. (1998). A pencil and paper instrument to diagnose students' conceptions of breathing, gas exchange and respiration. Australian Science Teachers Journal, 44(2), 55-60.

Nakhleh, M.B.J. (1994). A review of microcomputer-based labs: How have they affected science learning? Computers in Mathematics and Science Teaching, 13(4), 367-381.

Novak, J.D., \& Gowin, D.B. (1984). Learning How to Learn. Cambridge: Cambridge University Press.

Öner, F., \& Arslan, M. (2005). The effect of teaching on learning level with concept maps in the electrical unit of primary school $6^{\text {th }}$ grade science lesson. [İlköğretim 6. sınıf fen bilgisi dersi elektrik ünitesinde kavram haritaları ile öğretimin öğrenme düzeyine etkisi]. The Turkish Online Journal of Educational Technology, 4(4), 163-169.

Osborne, R., \& Freyberg, P. (1996). Learning in Science. United States: Heineman

Osborne, R.J., \& Wittrock, M.C. (1983). Learning science: A generative process. Science Education, 67(4), 489-508.

Pittman, K.M. (1999). Student-generated analogies: Another way of knowing? Journal of Research in Science Teaching, 36(1), 1-22.

Posner, J.G., \& Gertzog, W.A. (1982). The clinical interview and the measurement of conceptual change. Science Education, 66(2), 195-209.

Saka, A., \& Akdeniz, A.R. (2004). Change of misconceptions about genetics according to different levels. [Genetik konusuna ait kavram yanılgılarının farklı seviyelere göre değişimi]. Sakarya University Journal of Education Faculty, 7, 188-209.

Saka, A., Cerrah, L., Akdeniz, A.R., \& Ayas, A. (2006). A cross-age study of the understanding of three genetic concepts: How do they image the gene, DNA and chromosome? Journal Science Education Technology, 15(2), 192-202.

Şan, İ. (2008). The Effect of the Topic Transport System in Plants that is Being Taught with Concept Maps at the $2^{\text {nd }}$ Class of Biology Lesson to the Success. Konya: Unpublished Master's Thesis, Selçuk University, Institute of Educational Sciences.

Smith, E.L., \& Blakeslee, T.D. (1993). Teaching strategies associated with conceptual change learning in science. Journal of Research in Science Teaching, 30(2), 111-112.

Stofflett, R.T. (1994). The accommodation of science pedagogical knowledge: The application of conceptual change constructs to teacher education. Journal of Research in Science Teaching, 31(8), 787-810.

Treagust, D.F. (1988). The development and use of diagnostic instruments to evaluate students' misconceptions in science. International Journal of Science Education, 10, 159-169.

Wang, T., \& Andre, T. (1991). Conceptual change text versus traditional text application questions versus no questions in learning about electricity contemporary. Educational Psychology, 16, 103-116.

Watson, J.D., \& Crick, F.H.C. (1953). A structure for deoxyribose nucleic acid. Nature, 171, 737-738.

Wood-Robinson, C., Lewis, J., \& Leach, J. (2000). Young people's understanding of the nature of genetic information in the cells of an organism. Educational Research, 35(1), 29-36.

Yıldırım, M. (2008). Evaluation of the Transition from Scientific Knowledge to Teacher Knowledge with Didactic Transposition theory Approach on the Genetics Unit in Primary Science and Technology Course. İstanbul: Unpublished Doctoral Thesis, Marmara University, Institute of Educational Sciences. 